\title{
Genetic diversity assessment of aegilops germplasm by RAPD molecular markers
}

\author{
Baghizadeh, Amin ${ }^{*}{ }^{1}$ and Khosravi ,Sahar ${ }^{2}$ \\ ${ }^{1}$ Department of Biotechnology, International center for science, high technology \& \\ environmental sciences, Kerman, Iran \\ ${ }^{2}$ Islamic Azad University-karaj Branch, Iran \\ *Corresponding author. E-mail address:amin_4156@yahoo.com
}

\begin{abstract}
Study of the genetic diversity in plant inherited stores in order to classify the germplasm regarding resistance to biotic and abiotic stress and also preventing from genetic erosion is one of the basic and fundamental steps in the most breeding programs. Iran is one of the most important centers of genetic diversity due to having different climates and the old civilization. In order to distinguish and evaluate different genetic of aegilops germplasm, which were collected from west part of the Iran, 80 ecotypes of aegilops by RAPD molecular marker were assessed .DNA extraction was done by modified CTAB method. After DNA extraction stages, complement gene locuses were amplified by 18 RAPD primers. These primers produced 183 bands, that 151 bands (about $82 \%$ ) were polymorphic. Cluster analysis based on the resulting data was performed using UPGMA method and Dice's similarity coefficient in NTSYS software. The resulting dendogram categorized the accessions into 8 groups in $69 \%$ similarity. Principle Component Analysis (PCA) was performed too, 2 and 3 dimensions graphs using 18 primers were drawn.
\end{abstract}

Keywords : aegilops, genetic diversity, RAPD molecular marker, NTSYS software

\section{INTRODUCTION}

Aegilops is a genus of plants generally known as goatgrasses and belonging to the grass family, Poaceae. There are about 23 species and numerous sub species in the genus. Various members of the genus are classed as agricultural weeds. Growing through the winter, they resemble winter wheat. They are able to hybridize with various types of wheat and are sometimes classified as members of the wheat genus, Triticum. Aegilops is a winter annual grass, vegetatively similar to wheat in the seed stage. The leaves are alternately arranged with auricles at their base and occasional hairs extending along the margins. The flower spike is cylindrical and distinct from wheat. Two to four flowers are arranged in each of the spikelets which form the elongate cylindrical spike. It is jointed in appearance and each joint contains one to three seeds. The glumes on the top spikelet have long awns. The seed of jointed goatgrass ripens before winter wheat and shatters easily. The genus Aegilops L. contains approximately 23 species of diploid and polyploid annual grasses, which originated around the Mediterranean region and in Western and Central Asia (Slageren 1994). one of the basic legs of plant breeding is access and information of amount of diversity in genetic sets and different stages of breeding projects. Estimating of genetic composition of field crops and or genetic sets and also appointment of relationship between them have been usual since very olden times. From a historical point of view, this estimating has accomplished based on sexual organs biology, ecogeographical data, biology, pigments, pedigrees and assessment of agricultural characteristics. Although these markers and similar ways of genetic diversity estimating are usually very useful, but as for wide development in connection to molecular biology, more possibilities is created that can be undertaker for superior needs in connection to development of markers for assessment and estimating of genetic diversity of animal and plant masses. Between different aspects of usage of DNA based markers, DNA based fingerprinting has been the most interesting. Attractiveness of DNA based fingerprinting is because of its differentiation ability, pragmatism and abundance. Molecular markers are very important and strong implements for assessment of genetic relationships, selection of superior plants and study of similarity or dissimilarity between different samples. Many of DNA markers have been introduced yet. These markers differ from each other for polymorphism degree, dominance or co dominance, distribution in chromosome surface, 
repeatability, dependence or independence to DNA sequencing and etc.

Selection of the best marker system depends on aim of research and ploid level of studied being (Dehghan et al.,2008; naghavi et al.,2005). Based on morphological and genetic analysis, the genusis separated into five categories: Aegilops, Comopylum, Cylindropyrum, Sitopsis and Vertebrata, with combinations of the genomes $\mathrm{C}, \mathrm{D}, \mathrm{M}, \mathrm{N}, \mathrm{S}$ and $\mathrm{U}$ (Slageren 1994). many cytoplasmic and cytological studies (e.g., Tsunewaki et al., 1976; Teoh and Hutchinson, 1983) and an isozyme analysis (e.g., Benito et al., 1987) were done to reveal the genome relationships of Triticum-Aegilops species. More recent analyses have been focused on molecular markers in nuclei (DvoÉák and Zhang, 1992; Sasanuma et al., 1996 Wang et al., 2000; Huang et al., 2002a, b; Sallares and Brown, 2004) or organelles (Tsunewaki and Ogihara, 1983; Terachi and Tsunewaki, 1986; Ogihara and Tsunewaki, 1988; Terachi and Tsunewaki, 1992).

\section{MATERIAL AND METHODS}

Plant material: 80 ecotypes of aegilops were collected from west part of the Iran, (Table : 1)

Table 1 : collected aegilops ecotypes

\begin{tabular}{|l|l|}
\hline \multicolumn{1}{|c|}{$\begin{array}{c}\text { Region } \\
\text { of collection }\end{array}$} & No of Ecotype \\
\hline zanjan province & $1-2-3-4-5-6-7-8-9-10$ \\
\hline kordestan province & $11-12-13-14-15-16-17$ \\
\hline kermanshah province & $18-19-20-21-22-23-24$ \\
\hline ilam province & $25-26-27-28-29-30-31-32$ \\
\hline lorestan province & $33-34-35-36-37-38-39-40-41-42-43$ \\
\hline hamedan province & $44-45-46-47-48-49$ \\
\hline $\begin{array}{l}\text { Chaharmahal \& bakhtiari } \\
\text { province }\end{array}$ & $50-51-52-53-54-55-56-57$ \\
\hline Khozestan province & $58-59-60-61-62-63-64-65-66-67-68-69$ \\
\hline markazi province & $70-71-72-73-74-75$ \\
\hline $\begin{array}{l}\text { Khohkiloei \& boerahmad } \\
\text { province }\end{array}$ & $76-77-78-79-80$ \\
\hline
\end{tabular}

\begin{tabular}{|l|l|}
\hline 1. initial denaturation programme & 2 min at $94{ }^{\circ} \mathrm{C}$ \\
\hline \multirow{3}{*}{ 2. 40 cycles programme } & 1 min at $92{ }^{\circ} \mathrm{C}$ \\
\cline { 2 - 2 } & $1 \mathrm{~min}$ at $35{ }^{\circ} \mathrm{C}$ \\
\cline { 2 - 2 } 3. end programme of completion of DNA extension & 1 min at $72{ }^{\circ} \mathrm{C}$ \\
\hline
\end{tabular}

The PCR products were separated by electrophoresis in $1 \%$ agarose gel and subsequently stained with ethidium bromide (omar\&john,1997;
DNA extraction: The modified CTAB method used for this purpose. In this method, high salt concentration and polyvinylpyrrolidone (PVP) in the extraction buffer used in order to prevent the solubilization of polysaccharides and polyphenols in the DNA extract, respectively. Mild temperature conditions during extraction and precipitation retained. To better lysis of tissue and more obtain of DNA, the sample in extraction buffer incubated in water bath at $55^{\circ} \mathrm{C}$ for overnight. For completely proteins removal, was repeat chloroformisoamylalcohol step 4-5 time. DNA precipitation was did using isopropanol at $25^{\circ} \mathrm{C}$ for 1 hour, then the pellet was washed using wash buffer to remove contaminants. Finally, the pellet dissolved in TE buffer. DNA quantity and quality were estimated both using an UV spectrophotometer by measuring absorbencies at $\mathrm{A} 260$ and $\mathrm{A} 280$ and $0.8 \%$ agarose gel electrophoresis by comparing band intensity with $\lambda$ DNA of known concentrations. The results showed that the extracted DNA had desirable concentration and quality (Dehghan et al.,2008)

PCR amplification: To perform PCR (Polymerase Chain Reaction), the directions of Wantorp et al., with some changes was used.PCR mix contained : $1 \mu \mathrm{L}$ template DNA in $50 \mathrm{ng} / \mu \mathrm{L}$ concentration ; $0.3 \mu \mathrm{L}$ Taq DNA polymerase in 5 unit/ $\mu \mathrm{L}$ C. ; $2.5 \mu \mathrm{L}$ reaction buffer in $10 x$ C. $[500 \mathrm{mM} \mathrm{Mgcl} 2$ and Tris-Hcl $(\mathrm{PH}=8.4)]$; $2 \mu \mathrm{L} \mathrm{Mgcl}_{2}$ in $50 \mathrm{mM}$ C. ; $2.5 \mu \mathrm{L}$ dNTP in $2.5 \mathrm{mM}$ C. ; $2 \mu \mathrm{L}$ primer in $2 \mu \mathrm{M} \mathrm{C}$. ; $14.7 \mu \mathrm{L} \mathrm{ddH}_{2} \mathrm{O}$ .Final volume of reaction solution was

$25 \mu \mathrm{L}$.PCR reactions were performed by 18 random primers having 10 nucleotide(table 2) in eppendorf thermal cycler apparatus.PCR amplification was performed by following parameters

wantorp et al,2006; Williams et al,1990;). 100 bp size marker was used to score achieved bands 
Agric. Biol. J. N. Am., 2011, 2(2): 197-202

Table 2 : Applied random 10 nucleotide primers

\begin{tabular}{|c|c|c|c|}
\hline primer sequence & primer specified code & primer sequence & primer specified code \\
\hline $\begin{array}{l}\text { GGTCTCCTAG } \\
\text { CGGAGAGCGA } \\
\text { CCGGCATAGA } \\
\text { TGGGCTCGCT } \\
\text { ACTTGTGCGG } \\
\text { CCCACTGACG } \\
\text { CTGAGGAGTG } \\
\text { GGTCAACCCT } \\
\text { GCGGGAGACC } \\
\text { CCTCACCTGT }\end{array}$ & $\begin{array}{l}\text { A(sina gene) } \\
\mathrm{B}(\text { sina gene) } \\
\mathrm{C}(\text { sina gene) } \\
\mathrm{D}(\text { sina gene) } \\
\mathrm{E} \text { (sina gene) } \\
\mathrm{F}(\text { sina gene) } \\
\mathrm{G}(\text { sina gene) } \\
\mathrm{H} \text { (sina gene) } \\
\mathrm{I}(\text { sina gene) } \\
\mathrm{J}(\text { sina gene) }\end{array}$ & $\begin{array}{l}\text { CTCCCTGAGC } \\
\text { GTCCCAGAGC } \\
\text { TTCCCCGTCG } \\
\text { TTCCCCGCCC } \\
\text { GAGGGCGTGA } \\
\text { GAGGGCAAGA } \\
\text { GGGCACGCGA } \\
\text { GAGGGCGAGG }\end{array}$ & \begin{tabular}{|l}
53 (sina gene) \\
54 (sina gene) \\
62 (sina gene) \\
$63($ sina gene $)$ \\
$66($ sina gene) \\
$69($ sina gene $)$ \\
$70($ sina gene) \\
71 (sina gene)
\end{tabular} \\
\hline
\end{tabular}

\section{RESULTS AND DISCUSSION}

Applied 18 primers produced183 evident bands. These bands were graded in the form of " o\&1 matrix "in Excel software, that were in the order of presence of band : 1 , and the absence of band : 0 . 151 bands (about 82\%) of total bands were polymorphic (Fig 1). Analysis of resulting data(o\&1 matrix) was performed using UPGMA method and Dice's similarity coefficient in NTSYS software The resulting dendrogram categorized the accessions into 8 groups in 69\% similarity (fig1 and fig2) (Rohlf, 1993).

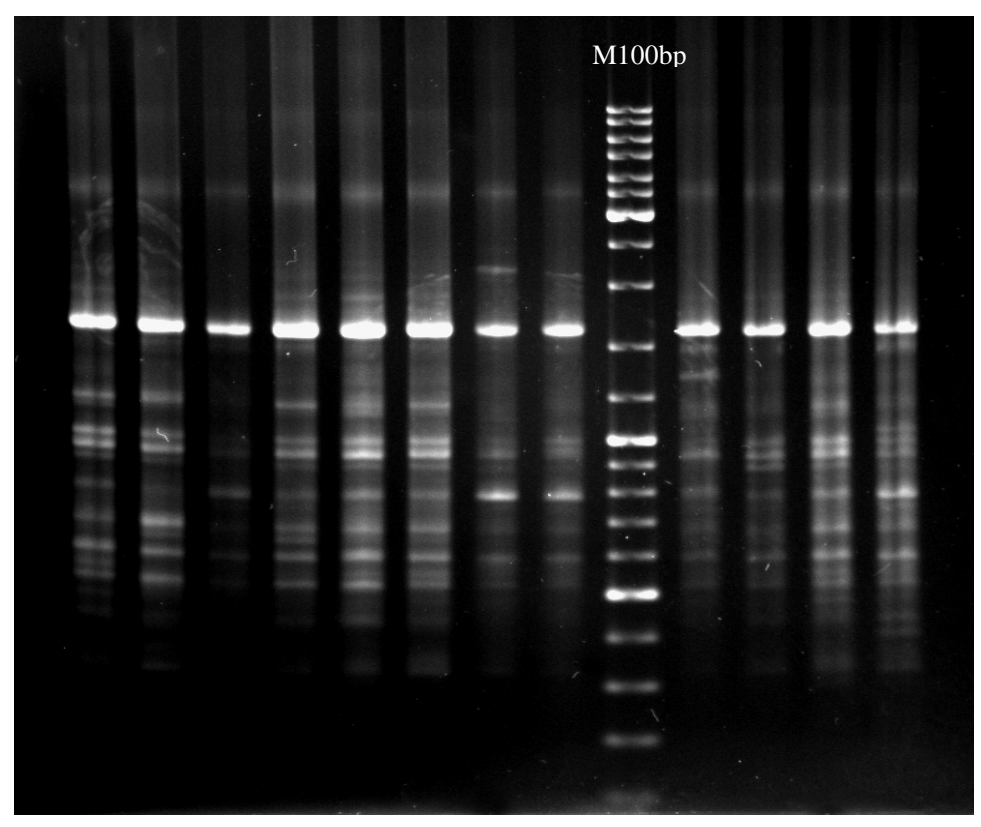

Fig1: sample of electrophoresis in $1 \%$ agarose gel 


\section{Principle Coordinate Analysis (PCA):}

PCA was performed too 2 and 3dimensions graphs using 18 primers were drawn (Figs $3 \& 4$ ). Achieved classification results of cluster

analysis didn't agree with results of principle component analysis sufficiently (Rohlf, 1993).
Since values of first three components as follows :

$\mathrm{h}_{1}=22.14 \% \quad, \quad \mathrm{~h}_{2}=8.7 \% \quad, \quad \mathrm{~h}_{3}=6.24 \%$

and these three components explain $37.08 \%$ of diversity of evaluated ecotypes totally, it seems that selection of primers has been suitable and classification based on cluster analysis is better than 2 and 3 dimensions graphs.

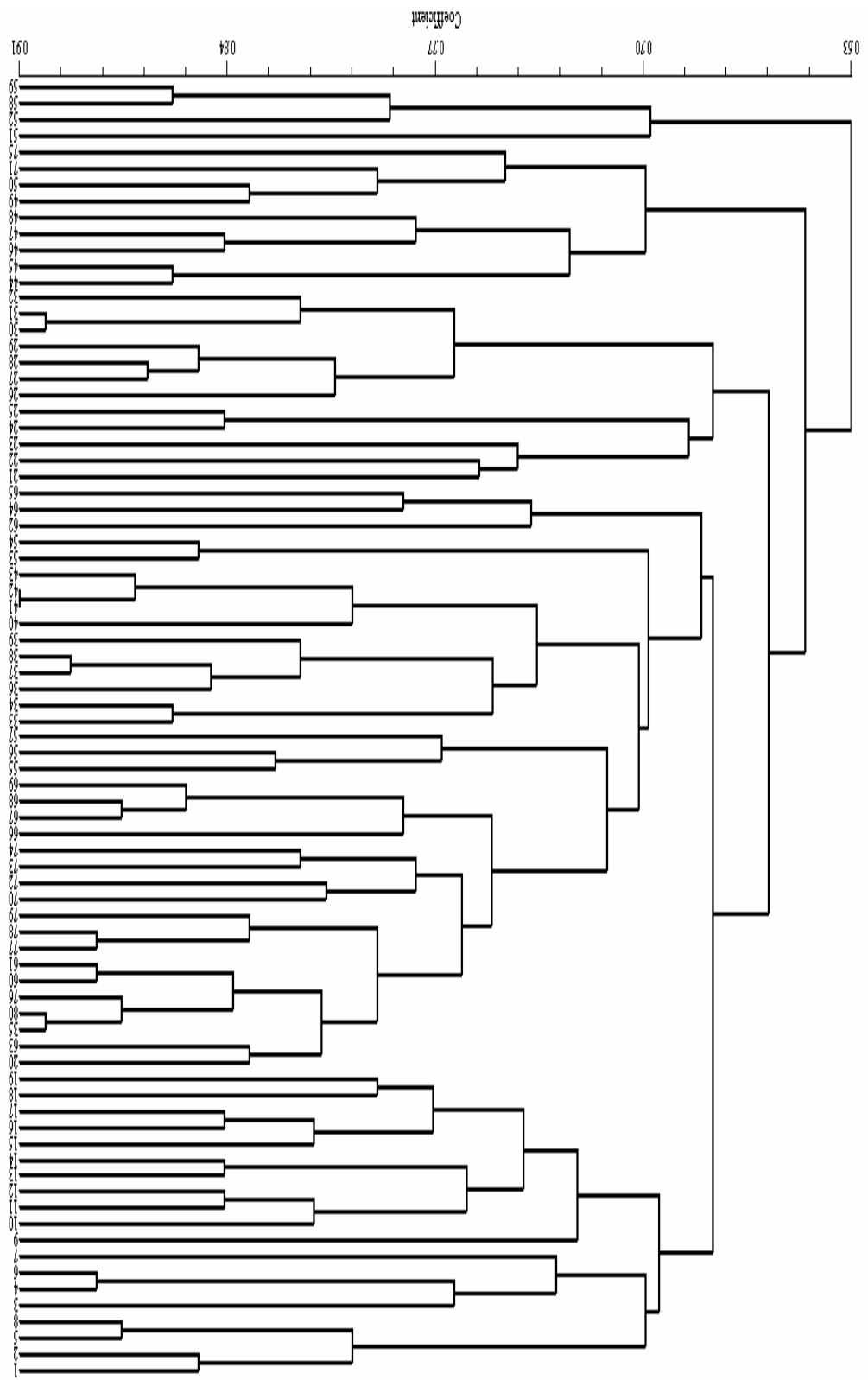

Fig 2: Achieved dendrogram by UPGMA method and Dice's similarity coefficient for 80 ecotypes using 18 primers 
Agric. Biol. J. N. Am., 2011, 2(2): 197-202

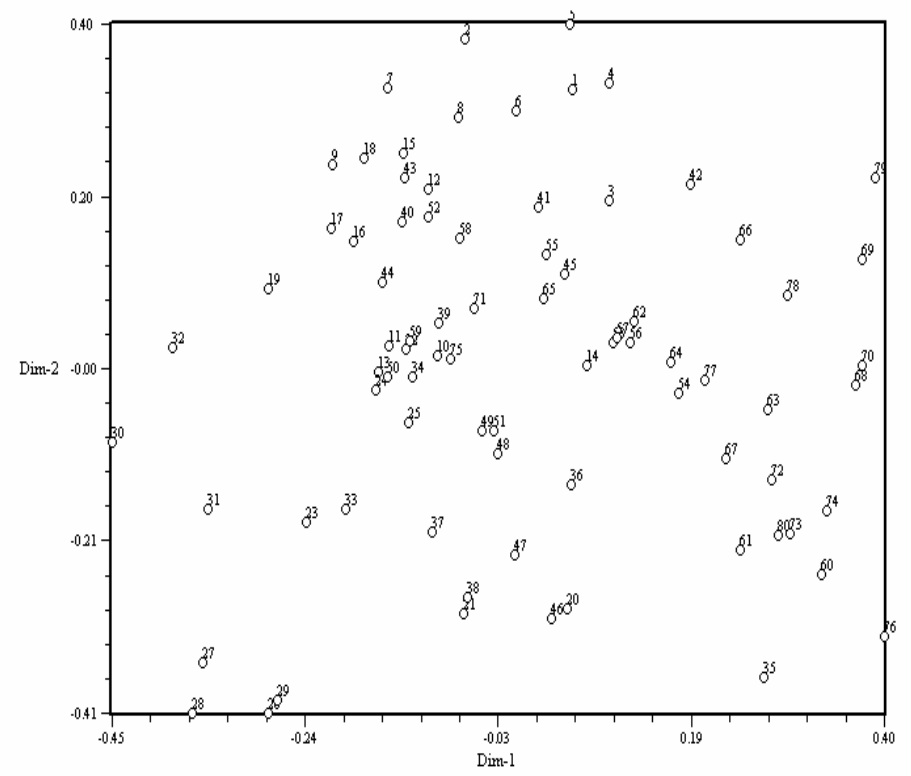

Fig 3 : Two dimensions graph related to Principle component analysis for 80 ecotypes using 18 primers

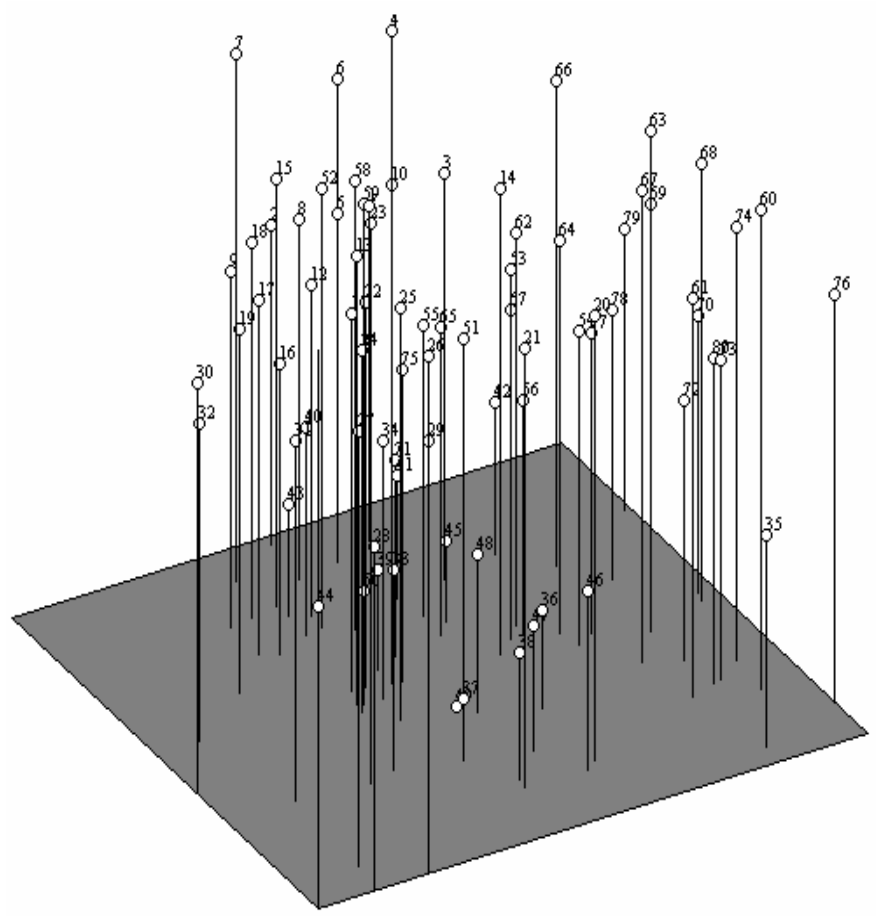

Fig 4 : three dimensions graph related to Principle component analysis for 80 ecotypes using 18 primers 


\section{ACKNOWLEDGMENT:}

This study was supported and done in International center for science, High technology \& environmental sciences, Kerman, Iran .

\section{REFERENCES}

Benito C. A. M. Figueiras M. T. Gonzalez-Jaen 1987 Location of genes coding isozyme markers on Aegilops umbellulata chromosomes adds data on homeology among Triticeae chromosomes. Theoretical and Applied Genetics 73: 581-588.

Dehghan, S., Baghizadeh, A., Ranjbar, A.(2008) Genetic diversity assessment of Bunium persicum of Kerman province by RAPD molecular markers. In : proc. $2^{\text {nd }}$.nat.symp. of cellular \& molecular biology. Kerman. Iran.pp : 115-117.

DvoÉák J. H. B. Zhang 1992 Reconstruction of the phylogeny of the genus Triticum from variation in repeated nucleotide sequences. Theoretical and Applied Genetics 84: 419-429.

Huang S. A. Sirikhachornkit J. D. Faris X. Su B. S. Gill R. Haselkorn P. Gornicki 2002a. Phylogenetic analysis of the acetyl-CoA carboxylase and 3-phosphoglycerate kinase loci in wheat and other grasses. Plant Molecular Biology 48: 805-820.

Naghavi, M.R.,Ghareyazi, B.,Hosseini, Gh.(2005) Molecular markers. Tehran university press. Tehran. Iran.pp : 88-100.

Ogihara Y. K. Tsunewaki 1988 Diversity and evolution of chloroplast DNA in Triticum and Aegilops as revealed by restriction fragment analysis. Theoretical and Applied Genetics 76: 321-332.

Omar Bagarsa ,John Hensen(1997) In situ pcr techniques. John Wiley press.

Rohlf, F.J.(1993) NTSYS-PC Numerical taxonomy and Multivariate Analysis System. Applied Biostatistics Inc., New York

wantorp,L.A.,Kocyan,R.Van Donkelaar and S.S.Renner(2006) Toward a inferences from the chloroplasm tml Region and the rbcl- atpB spacer. Systematic Botany. 31(3) : 586- 589.
Sallares R. T. A. Brown 2004 Phylogenetic analysis of complete $5^{\prime}$ external transcribed spacers of the $18 \mathrm{~S}$ ribosomal RNA genes of diploid Aegilops and related species (Triticeae, Poaceae). Genetic Resources and Crop Evolution 51: 701-712 .

Sasanuma T. N. T. Miyasita K. Tsunewaki 1996 Wheat phylogeny determined by RFLP analysis of nuclear DNA. 3. Intra- and interspecific variations of five Aegilops species. Theoretical and Applied Genetics 92: 928-934.

Slageren MW. 1994. Wild wheats: a monograph of Aegilops L. and Amblyopyrum (Jarib \& Spach) Eig (Poaceae). Wageningen Agricultural University and International Center for Agricultural Research in the Dry Areas.

Teoh S. B. J. Hutchinson 1983 Interspecific variation in Cbanded chromosomes of diploid Aegilops species. Theoretical and Applied Genetics 65: 31-40 .

Terachi T. K. Tsunewaki 1986 The molecular basis of genetic diversity among cytoplasms of Triticum and Aegilops. 5. Mitochondrial genome diversity among Aegilops species having identical chloroplast genomes. Theoretical and Applied Genetics 73: 175181.

Terachi T. K. Tsunewaki 1992 The molecular basis of genetic diversity among cytoplasms of Triticum and Aegilops. VIII. Mitochondrial RFLP analysis using cloned genes as probes. Molecular Biology and Evolution 9: 917-931.

Tsunewaki K. Y. Ogihara 1983 The molecular basis of genetic diversity among cytoplasms of Triticum and Aegilops species. II. On the origin of polyploid wheat cytoplasms as suggested by chloroplast and restriction fragment patterns. Genetics 104: 155-171.

Wang J.-B. C. Wang S.-H. Shi Y. Zhong 2000 ITS regions in diploids of Aegilops (Poaceae) and their phylogenetic implications. Hereditas 132: 209-213 .

Williams,j.G.k., kubelik,A.R., Livak,j.,Rafalski,JA.and tingey, s .v. , 1990.DNA polymorphisms amplified by arbitrary primers are useful as Genetic markers.nueleic Acids research , 18:6531-6535. 